\title{
Periphytic algal communities are highly influenced by substrate types in small pond, not large floodplain lake
}

\author{
Baogui Liu $^{\mathrm{a}, \mathrm{b}}$, Wei Wang ${ }^{\mathrm{b}}$, Kuimei Qian ${ }^{\mathrm{c}}$, Jinying Xu ${ }^{\mathrm{d}}$, Xia Liu ${ }^{\mathrm{e}}$, Jiayi Wu ${ }^{\mathrm{b}}$, Yuwei Chen ${ }^{\mathrm{f}, *}$, Guoxiang Wang ${ }^{\mathrm{b}, *}$ \\ a School of Geography, Nanjing Normal University, Nanjing 210023 China \\ b School of Environmental, Nanjing Normal University, Nanjing 210023 China \\ c Xuzhou University of Technology, Xuzhou 221000 China \\ d Key Laboratory of Poyang Lake Environment and Resource Utilization of Ministry of Education and School of \\ Resources, Environmental \& Chemical Engineering, Nanchang University, Nanchang 330031 China \\ e State Key Laboratory of Lake Science and Environment, Nanjing Institute of Geography and Limnology, \\ Chinese Academy of Sciences, Nanjing 210023 China \\ f Nanchang Institute of Technology, Nanchang 330099 China
}

*Corresponding authors, e-mail: 976370923@qq.com, wangguoxiang@njnu.edu.cn

\begin{abstract}
Periphyton sampling in hydrologically flexible regions is costly because of diverse substrates and fluctuating inundation time. It remains an open question whether periphytic algae samples in floodplain lakes may be obtained by sampling some representative natural substrates instead. To obtain the answer, algal biomass, richness, diversity, and community compositions were compared on 9 types of substrates in two investigations: in a small concrete pond and in the Poyang Lake, a large floodplain lake. Results in the pond showed that the algal Shannon index and species number on Potamogeton crispus and withered Typha orientalis were substantially higher than those on T. orientalis in March; the algal biomass on $T$. orientalis was considerably lower than that on the other substrates in June. Conversely, no significant differences in periphyton communities were found between substrate types in the Poyang Lake. However, the redundancy analysis revealed that water depth (positively related to the colonization time) plays a key role in shifting the algal community in the Lake. Thus, our results suggest that for a precise estimation of primary production, species richness, community composition, and ecological status assessment in large floodplain ecosystems, periphytic algae must be sampled not only on adequate substrate types but also on different depth gradients.
\end{abstract}

KEYWORDS: attached algae, community structure, temporal pattern, floodplain

\section{INTRODUCTION}

Periphytic algae play an important role in shallow freshwater ecosystems [1] and are recognized as an excellent indicator of water quality changes [2]. Periphytic algal ecology has gained considerable interest among researchers [3], but little is known about the algae in floodplain systems. Given that substrates are diverse and inundation time fluctuates with seasons, periphyton sampling in floodplain lakes is labourintensive, time-consuming, and expensive. To reduce the cost of sampling, periphytic algal diversity was obtained by sampling some representative natural substrates or artificial substrates with similar shapes. However, this hypothesis is still controversial [4] because determining whether or not values of metrics collected from different substrates can be compared is important [5].

Periphyton abundance, diversity, species richness, and community composition on different substrates have been intensively compared in field studies in the past decades $[3,4,6]$. Biofilms growing on artificial substrates showed that the sampling time and site had significant effects on the abundances of associated bacteria [7]. Studies in one site, or more, within a small water body [6] concluded that substrate specificity affects the periphytic algal community. Conversely, studies in relatively large lakes [8] or between lakes [9] found that substrate characteristics seem to be of minor importance $[5,8]$. Besides, colonization by periphytic algae follows a predictable temporal pattern: first by low-profile diatoms, followed by long-stalked and large-rosette diatoms, and finally by filamentous green algae. A large enclosure experiment showed that periphytic biomass and nutrient state were sensitive to incubation time [10]. Similarly, a field experiment demonstrated that the contribution of autotrophic biomass decreased as total biomass increased over time [11]. Few studies, however, have analyzed the effect of substrate types for large floodplain lakes, and the results show that the colonization time of the algae is positively related to the water depth.

The time of colonization was related to disturbances or water level provided by flood pulses in floodplain lakes. For example, submerged macrophytes have the longest colonization time, and emergent macrophytes only inundate periodically during high water level season [12]. In addition, rocks at littoral sites of the river (approximately $0.5 \mathrm{~m}$ underwater surface) have the shortest colonization time [5]. The relative importance of substrate types and colonization time, however, has been rarely considered. We 
infer that colonization time which is related to water level variation could be more important than substrate types in the development of the periphyton community. Compare with studies conducted in experimental conditions, the relationships between host substrates and associated microalgae in natural freshwater ecosystems are largely unknown [13].

This study compared periphytic algal biomass, diversity, and community composition on different kinds of natural substrates in a concrete pond and a large floodplain lake. We hypothesized that the periphytic algal communities are influenced by the substrate types in the small pond, but water depth (positively related to the colonization time) would play a major role in manipulating the periphytic algal community in the large floodplain lake.

\section{MATERIALS AND METHODS}

\section{Sampling process}

We performed two investigations: one in a small concrete pond and another in a large floodplain lake (Fig. 1). The pond (length $\times$ width $\times$ depth $=$ $15 \mathrm{~m} \times 4 \mathrm{~m} \times 3 \mathrm{~m}$ ) had three cascade slopes and been installed in the Lake Poyang Laboratory for Wetland Ecosystem Research (116.06 E, 29.45 N), and it was designed to imitate the wetland ecosystem of Lake Poyang. The sediments and water in the pond were transported from this lake. During the study period, the incubation time was artificially controlled by fixing the water level. We pumped water into the pond when the water level starts arising (in February 2015) in Lake Poyang; at this time Potamogeton crispus and Typha orientalis start to germinate and grow; and at the same time withered plants from the last year were being inundated. We sampled periphytic algae with three replicates in the pond firstly in March (2015) (sampled substrates on: PC, P. crispus; TO, T. orientalis; and $\mathrm{TO}_{\mathrm{d}}$, withered $\mathrm{T}$. orientalis with one-month incubation and short colonization time) and then in June (2015) (sampled periphyton on substrates: PC, P. crispus; TO, T. orientalis; PCs, $P$ crispus var. small leaves; and PW, $P$. wrightii with four-month incubation and long colonization time). The pairwise comparisons of periphytic algal biomass and diversity on different substrates were used to examine the effects of substrate types. The comparison of periphytic algal community on the same substrates but with different colonization times was used to test the effects of colonization time.

We also sampled periphytic algae on four substrates in Lake Poyang (Fig. 1). We sampled algae attached on Vallisneria sp. (Va) at sites L1-L4; on Carex sp. (Ca) and Zizania sp. (Zi) at sites F1, F3, and F4; and on rocks (Ro) at sites R1-R4. Meanwhile, samples for water chemistry analysis were collected. Water depth was measured using a Speedtech SM-5 Portable Depth Sounder (SpeedTech Company, Montana, USA). Water transparency was measured using a Secchi disk. Water temperature, dissolved oxygen, $\mathrm{pH}$, and conductivity were measured in situ with a Hydrolab DataSonda 5 Multiprobe (Hach Company, Loveland, Colorado, USA). Total values of nitrogen, nitrate, ammonia, phosphorus, and orthophosphate were measured according to standard methods by the "American Public Health Association" [14].

\section{Determination of periphyton and data analysis}

The "Standard methods for the examination of water and wastewater" [14] and the limnological investigation methods for the periphyton community were used as the basic references. To minimize sampling loss of loosely attached algae, substrates with developed periphyton were always cautiously collected. We bathed whole substrates with periphyton in distilled water and stored them in plastic bags, and the bags were taken to the laboratory in dark coolers. Epiphytes on aquatic plants were sampled from $25 \mathrm{~cm}$ apical shoots to $20 \mathrm{~cm}$ bottom shoots of submerged macrophytes and vertically mixed together. Periphyton on fragile leaves was removed using soft brushes followed by ultrasonic washing. Periphyton on rocks was removed using brushes and scalpels [15]. Scraped periphytic algae samples were fixed with Lugol's iodine solution ( $4 \% \mathrm{v} / \mathrm{v})$. Scrapings were dispersed by vigorous shaking, a suitable volume was then transferred to a thinner version of the Sedgwick-Rafter or Palmer-Maloney cell, and a strip count was made [14]. Any suspensions in the cell that was too dense to count directly was discarded and replaced with a diluted sample. Species identification and cell density of periphytic algae were performed according to the methods of $\mathrm{Hu}$ [16]. Algae were counted from aliquots of three replicates of the same sample taken from each substrate using an Olympus BX41 microscope (Olympus Company, Tokyo Japan) at $100 / 600 x$ magnification; a minimum of 400 cells was counted. The biomass was converted from cell volume, assuming that $1 \mathrm{mg}$ of fresh-weight biomass was equivalent to $1 \mathrm{~mm}^{3}$ of volume. The mean cell volume was calculated using the appropriate geometric configurations [17]. The degree of dominance of periphytic algal biomass was calculated as follows: $Y=\left(n_{i} / N\right) \times f_{i}$, where $N$ is the total biomass of all sites; $n_{i}$ is the biomass of taxa I; $f_{i}$ is the frequency of species $i$ occurring in each site. If $Y>0.02$, then the taxa (species) were defined as the dominant taxa. Diversity was calculated from the biomass data according to the Shannon-Wiener (Shannon) index.

Analysis of variance (ANOVA) was conducted to compare the algal biomass, Shannon index and algal richness of the compared substrates. The data of each group were normally distributed and had a common variance (Levene's test). We computed Tukey HSD (Tukey Honest Significant Differences) for performing multiple pairwise-comparison between the means of groups. Non-metric multidimensional scaling 


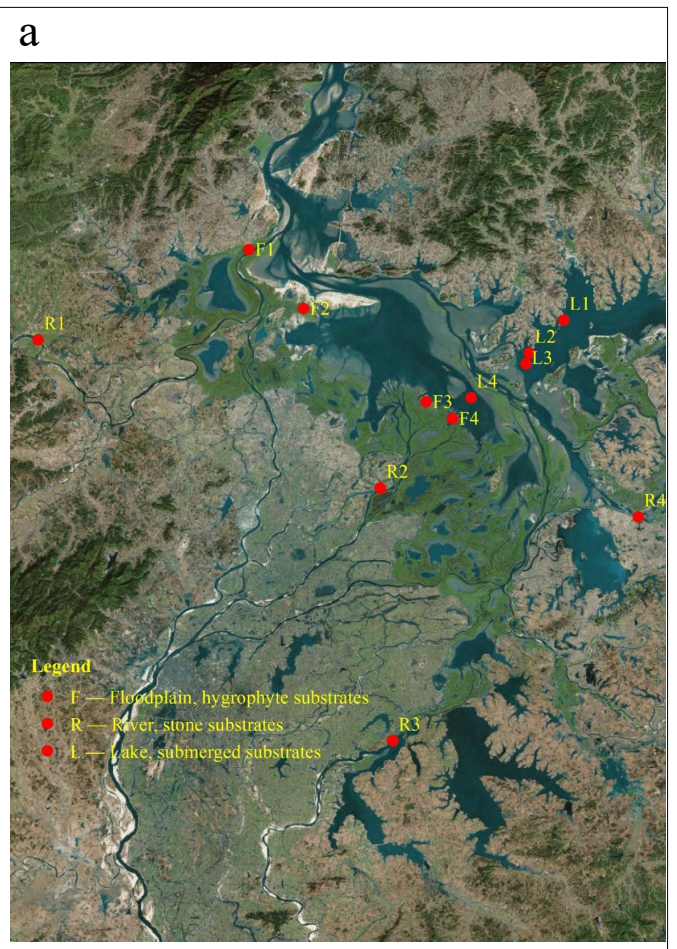

Field investigation in floodplain Lake Poyang
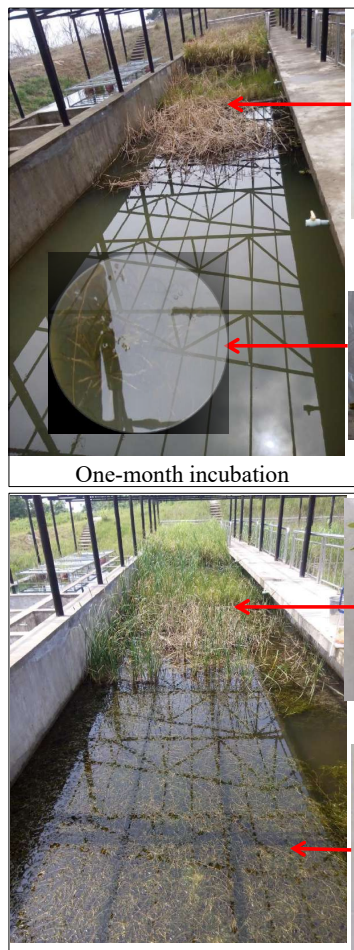

Four-month incubation

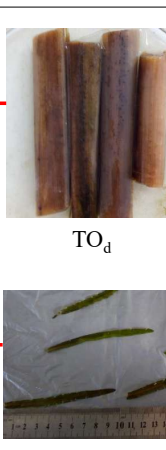

PC

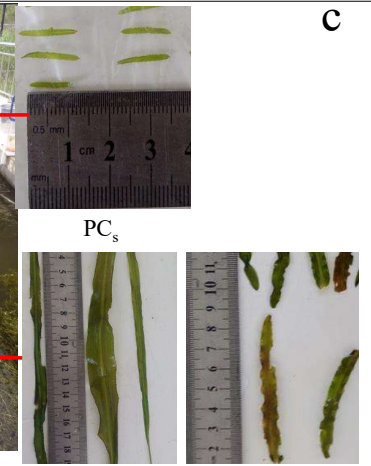

PW b

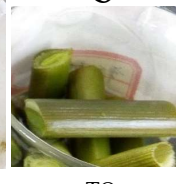

TO

PC

Fig. 1 (a) Sampling sites during the high-water-level season in the Poyang Lake; and (b,c) photographs of the pond and the substrates. (The 9 types of substrates are: PC, P. crispus; PCs, P. crispus var. small leaves; TO, T. orientalis; $\mathrm{TO}_{\mathrm{d}}$, withered T. orientalis; PW, P. wrightii; Va, Vallisneria sp.; Ca, Carex sp; Zi, Zizania sp.; and Ro, rocks.)

(NMDS) was used to determine whether the composition of periphytic algae differed among substrates; the significance was tested by analysis of similarity (ANOSIM). Redundancy analysis (RDA, because the gradient length on the first axis was lower than 3.0) between the matrix of occurrences of periphytic algal biomass and the most important environmental descriptors selected by forwarding selection was performed in the Poyang Lake. The Shannon index, ANOSIM, NMDS, and RDA were performed in R version 3.4.1 (R Core Team, 2017) with "vegan" package [18]. The relative abundance of the taxon was calculated on the basis of algal biomass.

The periphytic algae were classified into eight functional/ecological groups (Table S1) on the basis of their attachment strategies and growth forms [19]: prostrate or adnate attachment (PM), short stalks (SS), long stalks (LS), rosette or mucilage pads (RMP), filaments (FL), motile (MO), phytoplankton or very loosely attached algae (P), and unknown (U).

\section{RESULTS}

Fifty-three periphytic algal taxa were sampled (Table S1), most of which belonged to Chlorophyta (26 taxa), Bacillariophyta (13 taxa), and Cyanobacteria (6 taxa). The percentage of Cyanobacteria biomass was relatively higher in the pond with the long colonization time than in the Poyang Lake; however, no Cyanobacteria was observed with short time colonization. Within the Poyang Lake, the biomass percentage of Bacillariophyta was the highest on Vallisneria sp.; Cyanobacteria had the highest biomass percentage on rocks.

The effect of substrates on algal richness, biomass, and Shannon index is significant only in the pond (Fig. 2). With the short colonization time, the algal Shannon index and species number on P. crispus and withered T. orientalis were substantially higher than those on T. orientalis. With the long colonization time, the algal biomass on $T$. orientalis was considerably lower than that on other substrates. RDA analysis, however, showed that water depth (a proxy of colonization times in floodplain) was substantially correlated with periphytic algal community composition in the floodplain lake (Fig. 3).

On the basis of their attachment strategies and growth forms, filament algae were dominant on substrates with long colonization time; whereas adnate or pioneer algae were dominant on substrates with short colonization time (Fig. 4a and Fig. 4b). Compared with those in the pond, the algae in the field 

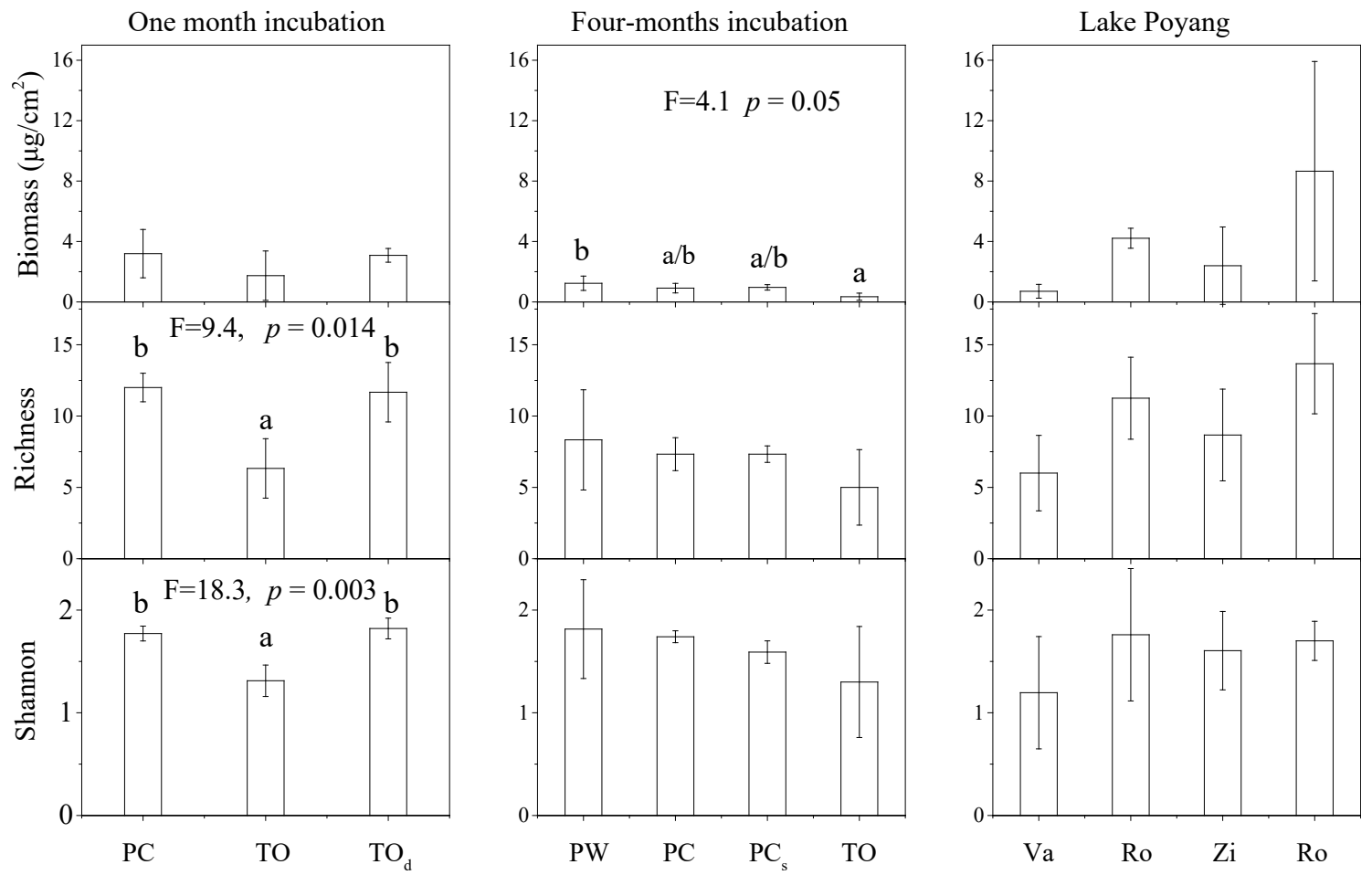

Substrate types

Fig. 2 Comparison of periphytic algal biomass, richness (number of taxon), and Shannon index. (The 9 types of substrates are: PC, P. crispus; PCs, P. crispus var. small leaves; TO, T. orientalis; $\mathrm{TO}_{\mathrm{d}}$, withered T. orientalis; PW, P. wrightii; Va, Vallisneria sp.; Ca, Carex sp; Zi, Zizania sp.; and Ro, rocks.)

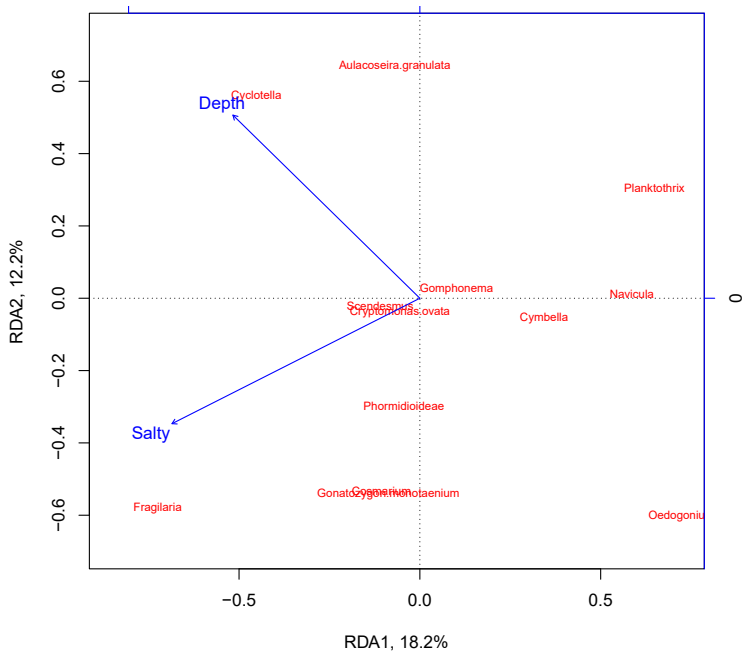

Fig. 3 Redundancy analysis between the matrix of periphytic algal biomass in the Poyang Lake and the two most important environmental descriptors selected by forward selection. Only species occurring more than four times are displayed.

were mostly characterized by communities with strong adhesion abilities (Fig. 4c).
The analysis of NMDS (Fig. 5) showed that substrate types had a remarkable impact on the attached algal taxonomical community only in the pond with long colonization time. Besides, the algal taxonomical community was more similar on substrates with similar architecture, for example, the leaves of $P$. crispus and P. wrightii.

\section{DISCUSSION}

Our results showed that the substrate's effects on periphytic algal biomass, species number, Shannon diversity, and community structure are highly associated with sampling scale or the colonization time. To our knowledge, few studies have focused on the sampling scale in explaining the effects of substrate types on the periphytic algal community.

In the present study, the results in the pond with long colonization time are consistent with those of previous studies that substrate types have significant effects on periphyton abundance, species richness, and species composition $[5,8,9]$. Live plants may inhibit algal biomass and diversity. In our results, Typha spp. may produce volatile oils that can negatively affect the growth of Cyanobacteria Microcystis aeruginosa [20] leading to diatoms dominance. Besides, 
$\begin{array}{llll}\square \mathrm{PM} & \square \mathrm{SS} & \mathrm{LS} & \square \mathrm{RMP} \\ \square \mathrm{FL} & \square \mathrm{MO} & \square \mathrm{P} & \square \mathrm{U}\end{array}$

b. Four months mesocosm

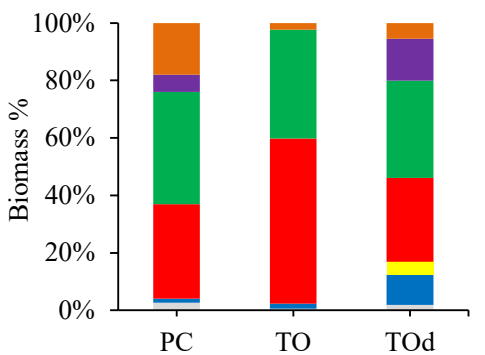

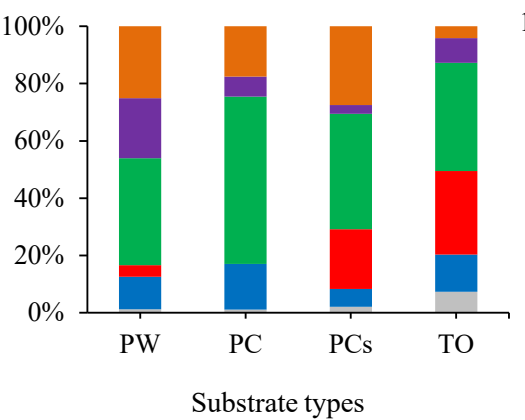

c. Floodplain lake

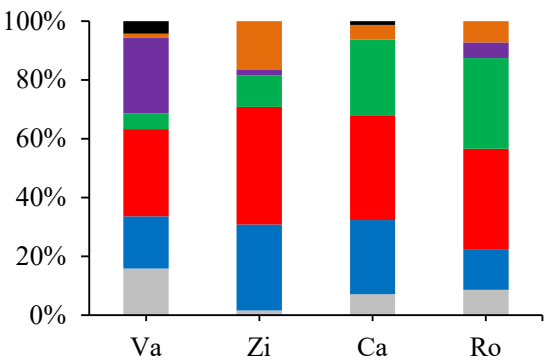

Fig. 4 Ecological groups of periphytic algal community are: PM, prostrate or adnate attachment; SS, short stalks; LS, long stalks; RMP, rosette or mucilage pads; FL, filaments; MO, mobile; P, phytoplankton; and U, unknown. (The 9 types of substrates are: PC, P. crispus; PCs, P. crispus var. leaves; TO, T. orientalis; $\mathrm{TO}_{\mathrm{d}}$, withered T. orientalis; PW, P. wrightii; Va, Vallisneria sp.; Ca, Carex sp; Zi, Zizania sp.; and Ro, rocks.)
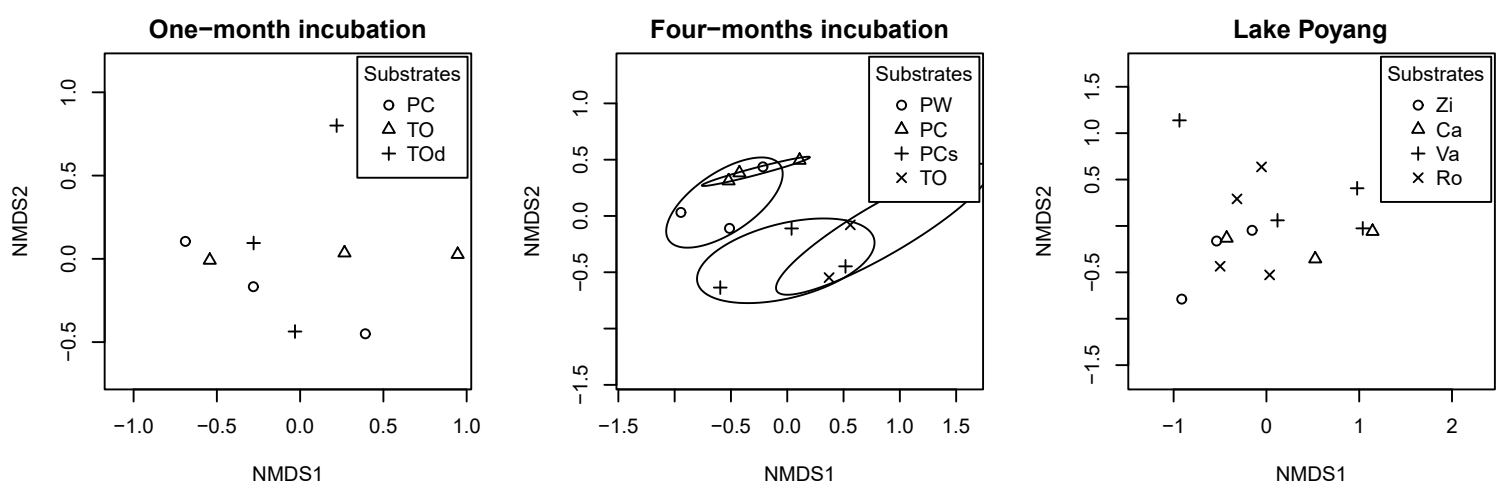

Fig. 5 Non-metric multidimensional scaling analysis of: (a) one-month incubation; (b) four-month incubation; and (c) the Poyang Lake. Ellipses are shown in the figure if the communities between groups are significantly (based on analysis of similarity, Fig. S1) different. (The 9 types of substrates are: PC, P. crispus; PCs, P. crispus var. small leaves; TO, T. orientalis; $\mathrm{TO}_{\mathrm{d}}$, withered T. orientalis; PW, P. wrightii; Va, Vallisneria sp.; Ca, Carex sp; Zi, Zizania sp.; and Ro, rocks.)

previous studies have revealed that the abundance and composition of periphyton on natural and artificial plants were not statistically different on leaves with a similar morphological architecture [21,22]. In our study, the algal taxonomical community on the leaves of $P$ crispus and $P$. wrightii were similar, but the biomass and the community structure differed remarkably on different substrates with distinct morphological architectures. However, our results showed that the Shannon diversity and species number of periphytic algae differed remarkably on different substrates only with short colonization time. According to algal attachment strategies $[3,19]$, pioneer algae with high attachment abilities are the first to colonize the surface of substrates, but most other algae cannot [23]. The differences of attachment ability may explain why the periphytic algal diversity and the number of species showed a considerable difference between substrate types at the preliminary stage. As micro-succession proceeded, the algal diversity and the number of species became more similar to each other, but the host substrates still influenced the algal biomass and community structure [24]. This inference was confirmed by the fact that the biomass ratio of filament algae with long colonization time showed a higher value than that with short colonization time.

Some researchers $[6,25,26]$ reported that substrates had a substantial effect on periphyton composition, whereas others reported the opposite $[8,27]$. The effects of microhabitats on periphyton are influenced by habitat heterogeneity, thus the interactions between substrate types and the surrounding environments may partly explain the inconsistent conclusions [28]. A probable explanation for this inconsistency is the environmental heterogeneity in the water columns, such as light condition, salinity, and hydrological disturbance [29]. For example, the substrate type effect was diminished by increasing incubation depth [30]. In 
general, tightly attached algae constitute over $60 \%$ of algal biomass in the Poyang Lake, suggesting that hydrological disturbance had a big effect on the periphyton community in our study. However, distinguishing these factors is difficult because plants and periphyton are intimately tied together [31]. This may explain why there are no remarkable differences that could be found on periphytic algal biomass, richness, or diversity between different substrate types in these types of lakes. Moreover, the RDA analysis indicated that salinity and colonization time (characterized by water depth) are important in shifting the algal community in the Poyang Lake, a result similar to that reported in other lakes [32]. Unlike small pond systems, the pattern of periphytic algae structure can be explained well by colonization time and other surrounding environmental variables instead of substrate types in the Poyang Lake. Floodplain lakes are complex integrated systems with diverse microhabitats and various incubation time for periphyton.

Due to constraints on the steady growth of living natural macrophytes, the length of algae colonization time in this study could not accurately be assessed. Although this limitation didn't affect the conclusions that can be drawn from the findings, more works with artificial substrates, however, are needed to quantitatively assess the effect of substrate type and incubation time on periphyton in the future.

\section{CONCLUSION}

The results of this study indicate that periphytic algal communities in the large floodplain lake are influenced by colonization time and the environment of water columns instead of substrate types. Hence, we conclude that to precisely estimate community composition in floodplain ecosystem periphytic algae must be sampled on adequate depth gradients of substrates types.

\section{Appendix A: Supplementary data}

Supplementary data associated with this article can be found at http://dx.doi.org/10.2306/scienceasia1513-1874. 2022.029.

Acknowledgements: This work was supported by the National Natural Science Foundation of China [Grant numbers 31600345 and 41671096]. We thank Jianjun Wang for his constructive suggestions on the writing. We would like to express our deep thanks to "KGSupport, http://www. kgsupport.com/" for editorial assistance.

\section{REFERENCES}

1. Lone L, Erik J (2009) Periphyton biomass, potential production and respiration in a shallow lake during winter and spring. Hydrobiologia 632, 201-210.

2. Chantal V, Christiane H, Antonella C, Bernadette PA (1998) Periphyton as an indicator of water quality in the St Lawrence River (Quebec, Canada). Environ Pollut 101, 13-24.
3. Tanja ZP, Melita M, Filip S, Dubravka S (2013) Periphytic algae colonization driven by variable environmental components in a temperate floodplain lake. Ann Limnol 49, 179-190.

4. Antonella C, Marie CA (1992) How artificial are artificial substrata for periphyton? JN Am Benthol Soc 11, 244-256.

5. Marina P, Charles DF (2005) Choice of substrate in algaebased water-quality assessment. J N Am Benthol Soc 24, 415-427.

6. Reet L, Markku R (2005) The composition and density of epiphyton on some macrophyte species in the partly meromictic Lake Verevi. Hydrobiologia 547, 137-150.

7. Xianlei C, Ling Y, Qiyue S, Luyao J, Randy AD, Ting W (2018) Properties of bacterial communities attached to artificial substrates in a hypereutrophic urban river. Amb Express 8, ID 22.

8. Hunter JC, Alan DS (2001) Variation in periphyton biomass and species composition in Lake Okeechobee, Florida (USA): distribution of algal guilds along environmental gradients. Arch Hydrobiol 152, 411-438.

9. Lars-Anders H (1992) Factors regulating periphytic algal biomass. Limnol Oceanogr 37, 322-328.

10. Na Z, Hongjing L, Erik J, Wei L (2013) Influence of substrate type on periphyton biomass and nutrient state at contrasting high nutrient levels in a subtropical shallow lake. Hydrobiologia 710, 129-141.

11. Guariento RD, Caliman A, Esteves FA, Bozelli RL, EnrichPrast A, Farjalla VF (2009) Substrate influence and temporal changes on periphytic biomass accrual and metabolism in a tropical humic lagoon. Limnologica 39, 209-218.

12. Xue D, Rongrong W, Guishan Y, Xiaolong W, Ligang X (2016) Responses of wetland vegetation in Poyang Lake, China to water-level fluctuations. Hydrobiologia 773, $35-47$.

13. Mutinova PT, Neustupa J, Bevilacqua S, Terlizzi A (2016) Host specificity of epiphytic diatom (Bacillariophyceae) and desmid (Desmidiales) communities. Aquat Ecol 50, 697-709.

14. American Public Health Association (2005) Standard Methods for the Examination of Water and Wastewater, Washington DC, USA.

15. Tarkowska-Kukuryk M, Mieczan T (2012) Effect of substrate on periphyton communities and relationships among food web components in shallow hypertrophic lake. J Limnol 71, 279-290.

16. Hongjun H (2006) The Freshwater Algae of China: Systematics, Taxonomy and Ecology, Science Press, China.

17. Helmut H, Claus-Dieter D, David K, Utsa P, Tamar Z (1999) Biovolume calculation for pelagic and benthic microalgae. J Phycol 35, 403-424.

18. Jari O, Guillaume B, Roeland K, Pierre L, Peter RM, Rb O, Gavin LS, Peter S, et al (2018) Community Ecology Package, Package 'vegan', Boston, USA.

19. Kalman T, Agnes B, Csilla SK, Judit P, Frederic R (2016) Trait-based ecological classifications for benthic algae: review and perspectives. Hydrobiologia 776, 1-17.

20. Wang H, Zhu H, Xia C, Zhang K, Zhang L, Wu Z (2010) An analysis of chemical constituents of volatile oil of Typh a latifolia and their algae inhibition activity. In: 2010 International Conference on E-Product E-Service and EEntertainment, Henan, China, pp 1-3. 
21. Jones IJ, Moss B, Eaton JW, Young JO (2000) Do submerged aquatic plants influence periphyton community composition for the benefit of invertebrate mutualists? Freshwat Biol 43, 591-604.

22. Beibei H, Haoping W, Yu C, Wei X, Erik J, Wei L (2017) Comparison of periphyton communities on natural and artificial macrophytes with contrasting morphological structures. Freshwat Biol 62, 1783-1793.

23. Qian W, Paul BH, Fuxing K (2014) Observations on attachment strategies of periphytic diatoms in changing lotic systems (Ottawa, Canada). Nova Hedwigia 99, 239-253.

24. van Dam AA, Beveridge MC, Azim ME, Verdegem MC (2002) The potential of fish production based on periphyton. Rev Fish Biol Fish 12, 1-31.

25. David E (2015) The ecology and palaeoecology of diatom-duckweed relationships. PhD thesis, Univ College London, UK.

26. Luciana AR, Gabriela SH (2017) Distribution of epiphytic diatoms on five macrophytes from a Pampean shallow lake: Host-specificity and implications for paleoenvironmental reconstructions. Diatom Res 32, 263-275.
27. Antonella C, Gaetano G, Silvia G, Susana A (1998) Epiphytic algae and macroinvertebrates on submerged and floatingâĂ $̌$ leaved macrophytes in an Italian lake. Freshwat Biol 39, 725-740.

28. Jones JI, Young JO, Eaton JW, Moss B (2002) The influence of nutrient loading, dissolved inorganic carbon and higher trophic levels on the interaction between submerged plants and periphyton. $J$ Ecol 90, 12-24.

29. Danger M, Lacroix G, Oumarou C, Benest D, Meriguet $J$ (2008) Effects of food-web structure on periphyton stoichiometry in eutrophic lakes: a mesocosm study. Freshwat Biol 53, 2089-2100.

30. Ivana T, Jelena J, Dušan K, Sladana P, Dragana P, Vesna K, Gordana SS (2018) Periphyton developed on artificial substrates: Effect of substrate type and incubation depth. Russian J Ecol 49, 135-142.

31. Grutters BM, Gross EM, van Donk E, Bakker ES (2017) Periphyton density is similar on native and non-native plant species. Freshwat Biol 62, 906-915.

32. Messyasz B, Kuczynska-Kippen N (2006) Periphytic algal communities: A comparison of Typha angustifolla L. and Chara tomentosa L. beds in three shallow lakes (West Poland). Polish $J$ Ecol 54, 15-27. 


\section{Appendix A. Supplementary data}
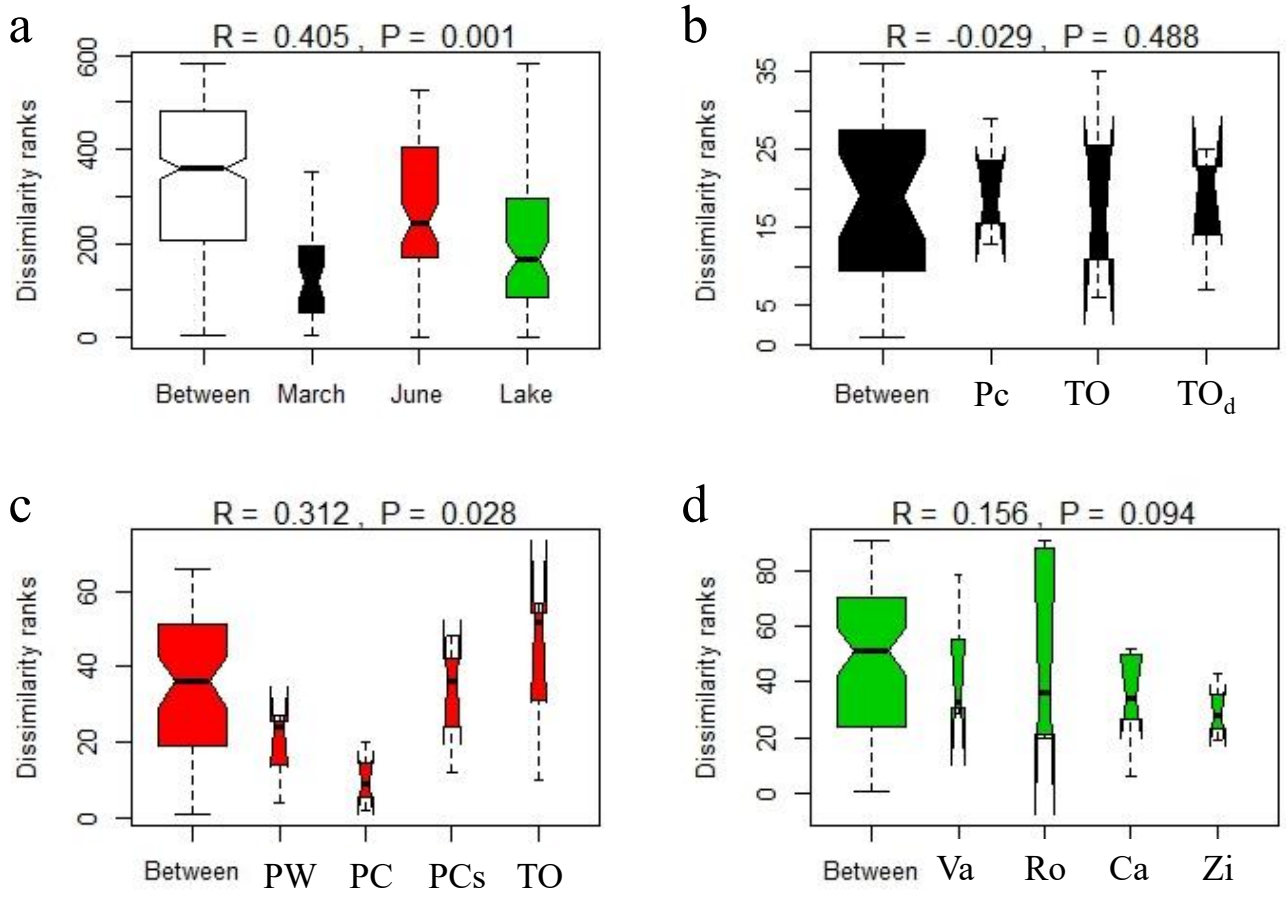

Fig. S1 Analysis of similarity (ANOSIM) between different groups of: (a) all groups; (b) one-month incubation; (c) fourmonths incubation; (d) Lake Poyang. (The 9 types of substrates are: PC, P. crispus; PCs, P. crispus var. small leaves; TO, T. orientalis; $\mathrm{TO}_{\mathrm{d}}$, withered T. orientalis; PW, P. wrightii; Va, Vallisneria sp.; Ca, Carex sp; Zi, Zizania sp.; and Ro, rocks.) 
Table S1 Algal taxa and their degree of dominance on different substrates. Taxa larger than 0.02 are shown in the table; those lesser than 0.02 are shown by “+”. Algal attachment strategies are as follows: PM, prostrate or adnate attachment; SS, short stalks; LS, long stalks; RMP, rosette or mucilage pads; FL, filaments; MO, mobile; P, phytoplankton; and U, unknown. (The 9 types of substrates are: PC, P. crispus; PCs, P. crispus var. small leaves; TO, T. orientalis; $\mathrm{TO}_{\mathrm{d}}$, withered T. orientalis; PW, P. wrightii; Va, Vallisneria sp.; Ca, Carex sp; Zi, Zizania sp.; and Ro, rocks.)

\begin{tabular}{|c|c|c|c|c|c|c|c|c|c|c|c|c|c|}
\hline \multirow[b]{2}{*}{ Taxa } & \multicolumn{3}{|c|}{ One-month incubation } & \multicolumn{4}{|c|}{ Four-month incubation } & \multicolumn{5}{|c|}{ Floodplain lake } & \multirow[b]{2}{*}{ Colony } \\
\hline & PC & TO & $\mathrm{TO}_{\mathrm{d}}$ & PW & PC & PCs & TO & $\mathbf{M}$ & Va & $\mathrm{Zi}$ & $\mathrm{Ca}$ & Ro & \\
\hline \multicolumn{14}{|l|}{ Cyanobacteria } \\
\hline Anabaena spp. & & & & & 0.07 & & & & & & & & FL \\
\hline Anabaenopsis sp. & & & & & & 0.18 & 0.08 & & & + & + & + & FL \\
\hline Oscillatoria spp. & & & & & & & & & & + & & + & FL \\
\hline Planktothrix sp. & & & & & & & & & 0.03 & + & + & 0.03 & FL \\
\hline Phormidioideae spp. & & & & & & + & & & & + & & + & FL \\
\hline Microcystis spp. & & & & & + & & & & & & & & $\mathrm{P}$ \\
\hline \multicolumn{14}{|l|}{ Bacillariophyta } \\
\hline Achnanthes sp. & + & + & 0.04 & 0.07 & 0.05 & 0.06 & 0.13 & 0.02 & + & & + & & SS \\
\hline Aulacoseira granulata & + & & 0.05 & & & & & & 0.07 & + & & + & MO \\
\hline Aulacoseira granulata var. angustissima & & & & & & & & & + & & + & & $\mathrm{U}$ \\
\hline Cocconeis sp. & & & & & & & & & + & & & & PM \\
\hline Cyclotella spp. & & & + & & + & & + & & 0.06 & + & + & & PM \\
\hline Cymbella spp. & & & 0.02 & & 0.04 & & & + & 0.05 & 0.24 & 0.07 & 0.12 & SS \\
\hline Eunotia spp. & & & & & & & & & + & & + & & PM \\
\hline Fragilaria spp. & 0.33 & 0.58 & 0.29 & + & & 0.14 & 0.10 & 0.37 & 0.20 & 0.40 & 0.35 & 0.34 & RMP \\
\hline Gomphonema spp. & + & & & + & & & & & + & 0.03 & + & + & SS \\
\hline Gyrosigma sp. & + & & + & & & & & + & & & & + & $\mathrm{PM}$ \\
\hline Navicula spp. & + & + & + & & & + & & + & + & + & 0.05 & 0.04 & $\mathrm{PM}$ \\
\hline Pinnularia spp. & + & & & + & & & + & + & + & & + & & $\mathrm{PM}$ \\
\hline Surirella spp. & 0.04 & & & & & & & & & & & & $\mathrm{P}$ \\
\hline \multicolumn{14}{|l|}{ Chlorophyta } \\
\hline Ankistrodesmus spp. & + & & + & + & + & & + & 0.02 & & + & & & $\mathrm{P}$ \\
\hline Chlorella spp. & & & & + & + & + & & + & & + & & + & $\mathrm{P}$ \\
\hline Cladophora sp. & & & + & & & & & + & & & + & 0.04 & FL \\
\hline Closterium sp. & + & & 0.02 & & & & & & & & & + & $\mathrm{P}$ \\
\hline Cosmarium granatum Breb & & & & & & & & 0.03 & & + & & & $\mathrm{P}$ \\
\hline Cosmarium regnellii & & & & & & & & & & + & & & $\mathrm{P}$ \\
\hline Cosmarium spp. & + & 0.02 & 0.02 & 0.23 & 0.13 & 0.14 & & & & 0.05 & 0.03 & + & $\mathrm{P}$ \\
\hline Crucigenia spp. & & & & & & & & & & + & & & $\mathrm{P}$ \\
\hline Eudorina spp. & & & & 0.03 & 0.02 & & & & & & & & MO \\
\hline Gonatozygon monotaenium & + & 0.02 & & 0.05 & & & & + & & + & 0.03 & + & FL \\
\hline Klebsormidium & & & & & & & & & & & & + & FL \\
\hline Mougeotia sp. & 0.2 & 0.16 & 0.15 & 0.05 & 0.16 & 0.14 & 0.09 & & & + & 0.02 & & FL \\
\hline Oedocladium & + & 0.02 & + & & & & & & & & & & FL \\
\hline Oedogonium spp. & 0.02 & 0.04 & 0.02 & 0.17 & 0.26 & 0.07 & 0.08 & 0.13 & + & 0.02 & 0.07 & 0.11 & FL \\
\hline Oocystis sp. & & & & & & & & & & + & & & $\mathrm{P}$ \\
\hline Pandorina spp. & & & & & & & & & & & & + & MO \\
\hline Pediastrum duplex & & & & & & & & & & + & & + & $\mathrm{P}$ \\
\hline Pediastrum tetras & & & & & & & & & & & & + & $\mathrm{P}$ \\
\hline Scenedesmus sp. & + & & & & & & + & & + & + & & + & $\mathrm{P}$ \\
\hline Schroederia sp. & & & & & & & & & & + & & + & $\mathrm{P}$ \\
\hline Spirogyra sp. & 0.04 & 0.03 & + & & 0.04 & & & + & & + & & & FL \\
\hline Spondylosium sp. & 0.03 & & & & & & & & & & & & FL \\
\hline Staurastrum sp. & & & & & & 0.02 & & + & & + & & & $\mathrm{P}$ \\
\hline Stigeoclonium sp. & & & 0.06 & & & & & & & + & 0.02 & & FL \\
\hline Tetraedron sp. & & & & + & & & & & & & & & $\mathrm{P}$ \\
\hline Ulothrix spp. & + & & & & & & & 0 & & + & + & + & FL \\
\hline Westella spp. & & & 0.03 & & & & & & & & & & LS \\
\hline Zygnema sp. & & & + & & & & & & & & & & FL \\
\hline \multicolumn{14}{|l|}{ Euglenophyta } \\
\hline Euglena oxyuris & & & & 0.02 & & & & & & & & & MO \\
\hline Phacus sp. & & & & + & & & & + & & & & & SS \\
\hline Trachelomonas sp. & & & & + & & & & & & & & & MO \\
\hline \multicolumn{14}{|l|}{ Dinophyta } \\
\hline Peridinium sp. & + & & & & & & & 0.02 & & & & & $\mathrm{P}$ \\
\hline \multicolumn{14}{|l|}{ Cryptophyta } \\
\hline Cryptomonas ovata & 0.03 & & & + & & + & 0.03 & + & 0.02 & + & & + & MO \\
\hline
\end{tabular}

